\title{
Pathogenicity and chemical control of Alternaria sp. on date palm (Phoenix dactylifera L.)
}

\author{
Abdulnabi Abbdul Ameer Matrood ${ }^{1}$, Claudia Adriana Ramírez Valdespino², Muhannad Abdulridha Al- \\ Waeli ${ }^{1}$, Mohammad Imad Khrieba ${ }^{3} \&$ Abdelhak Rhouma $^{4 *}$ \\ ${ }^{1}$ College of Agriculture, University of Basra, Iraq \\ ${ }^{2}$ Biohydrometallurgy Laboratory, Department of Environment and Energy, Center of Research in Advanced Materials, Chihuahua, Mexico \\ ${ }^{3}$ National Centre for Biotechnology (NCBT), Researcher Doctor at NCBT. Damascus, Syria \\ ${ }^{4}$ High Institute of Agronomy of Chott Mariem, 4042 Sousse, University of Sousse, Tunisia \\ *Email: abdelhak.rhouma@gmail.com
}

\section{ARTICLE HISTORY}

Received: 28 February 2021

Accepted: 08 April 2021

Published: 30 April 2021

\section{KEYWORDS}

Alternaria sp.

Date palm

Fungicide

Fusarium sp.

Pathogenicity
ABSTRACT

Recently, a wide range of symptoms including light yellow lesions gradually turning into brown stripes were noticed on date palm leaves in Iraq. In this context, the aim of this study were to isolate the phytopathogens associated with these symptoms, evaluate their pathogenicity and assess the efficacy of two fungicides (Score and Pentanol) under in vitro and in vivo conditions. Two fungal species (Alternaria sp. and Fusarium sp.) were isolated from the symptomatic leaves of date palm. The results of pathogenicity tested proved the ability of Alternaria sp. inoculated separately or in combination with Fusarium sp. to infect the leaves of date palm trees with disease severity index (DSI) values of $67.33 \%$ and $65.99 \%$, respectively. The effect of Score (88.76\%) and Pentanol $(82.91 \%)$ against Alternaria sp. was examined by poisoned food technique, which leads a significant increase in mycelial growth inhibition (for $300 \%$ of commercial recommended dose of fungicide). Test results indicate that prophylactic spraying of date palm leaves with Score or Pentanol effectively controlled Alternaria sp. with DSI values of $22.65 \%$ and $17.87 \%$, respectively. To control Alternaria sp. in field within integrated pest management strategies, chemical control using Score or Pentanol should be taken in consideration.

\section{Introduction}

Phoenix dactylifera L. (Arecaceae) is thought to be the oldest fruit tree grown in Iraq and is an important crop in term of the number of trees and their distribution. Date palm is widely considered as a strategic source of food security and an essential crop in the Iraqi economy (1). Date palm represents a source of income to many farmers in large parts of Iraq (2-4). Date palm production in Iraq was reported to be around 250 thousand tons, with an average of $1666.67 \mathrm{~kg} / \mathrm{ha}$ in 2017 (Iraqi ministry of agriculture).

The date palm is being affected by several pathogenic fungi amongst them are Alternaria sp., Fusarium sp., Phytophthora sp., Diplodia sp., Mauginiella sp., Mycosphaerella sp., Thielaviopsis sp., Glomerella sp., Phoma sp., Graphiola sp., Nigrospora sp., Chalara sp., Chaetosphaeria sp., Phomopsis sp. etc. These pathogens caused severe damages to different date palm parts such as stem, leaves, fruit and root leading to severe losses and reduction in total yield (5). Worldwide annual economic yield lose due to these pathogens have been estimated more at $50 \%$ in $2002(6,7)$.

Among these diseases are the bayoud, the most dangerous of which affects the date palm, especially in Morocco, Algeria and Mauritania and is caused by Fusarium oxysporum f. sp. albedinis, inflorescence rot caused by Thielaviopsis paradoxa or Mauginiella scaetae, leaf spot caused by Mycosphaerella tassiana and Alternaria spp., Khamedj or date palm inflorescences rot caused by Fusarium moniliforme or T. paradoxa, black scorch caused by T. paradoxa, leaf

(c) Matrood et al (2021). This is an open-access article distributed under the terms of the Creative Commons Attribution License, which permits unrestricted use, distribution and reproduction in any medium, provided the original author and source are credited (https://creativecommons.org/licenses/by/4.0/).

To cite this article: Matrood A A A, Valdespino C A R, Waeli M A A, Khrieba M I, Rhouma A. Pathogenicity and chemical control of Alternaria sp. on date palm (Phoenix dactylifera L.). Plant Science Today. 2021;8(2):386-391. https://doi.org/10.14719/pst.2021.8.2.1147 
blight caused by Glomerella cingulata, off-shoot decline caused by Chalara paradoxa, belaat disease caused by Phytophthora sp., apical drying of palm leaves caused by Alternaria sp. and Phoma sp. and leaf spot and yellowing diseases (8).

Leaf spot and yellowing diseases in date palms received less attention from researchers. There are several fungi capable of causing this disease, including Graphiola phoenicis (9), Nigrospora sphaerica (10), Alternaria spp. (11), Fusarium solani (12). However, most researchers agree that the causes of leaf spots and yellowing diseases in date palms are the genus Alternaria (7, 13-17).

Alternaria spp. is a genus of ascomycete fungi, belongs of Eumycotera subkingdom, form Dematiaceae family, Moniliales order, and Hypomycetes class. Some of the species Alternaria are the asexual anamorph of Pleospora ascomycete while others are thought to be anamorphs of Leptosphaeria (18).

One of the best alternatives to control plant pathogens is by using genetically resistant varieties and chemical treatments (17).

Score and Pentanol fungicides are widely used in agriculture in different parts of the world. Score is a systemic Triazole fungicide for long-lasting preventive and strong curative action against powdery mildew, many date palm diseases and rust disease in fruit trees (19). Score presented high efficacy against date palm diseases when tested under in vitro and in vivo conditions $(6-7,17)$. Pentanol is an active organic compound produced by plants and is a component of insect sex pheromones emitted (20). In Arabidopsis, it was reported that 3Pentanol can trigger plant systemic resistance against Pseudomonas syringae pv. tomato (6), making possible that Pentanol has an effect on many date palm disease.

Recently, a wide range of symptoms were remarked on date palm in Iraq which are light yellow lesions on peduncles and gradually developing to longitudinal pale brown stripes on the whole peduncle. Date fruits wilt usually from the bottom of the strand up and then the pedicel, peduncle and whole bunch wilt dry. The objectives of this investigation were to: (i) isolate the pathogens associated with these symptoms, (i) evaluate the pathogenicity of the isolated phytopathogens and (iii) determine the efficacy of two fungicides widely used by Iraqi farmers (Score and Pentanol) under in vitro and in vivo conditions.

\section{Materials and Methods}

\section{Phytopathogens isolation from date palm}

The sampling was done to collect diseased leaves of date palm (cv. Barhi) showing typical symptoms of spotting and yellowing from palm grove located in Basra, Iraq. Infected leaves were cut in small pieces $(0.5-1 \mathrm{~cm})$ and sterilized by soaking into $3 \%$ sodium hypochlorite $(\mathrm{NaOCl})$ for $2 \mathrm{~min}$ and washed with sterilized distilled water 3 times. The samples were dried and inserted on the surface of Petri dishes (9 $\mathrm{cm}$ in diameter) containing Malt Extract Agar (MEA) medium amended with streptomycin $(60 \mu \mathrm{g} / \mathrm{ml})$. In each Petri dish, seven fragments were placed (with total of 30 Petri dishes). The plates were incubated in the dark at $25 \pm 2{ }^{\circ} \mathrm{C}$ for 5-7 days and then examined for fungal growth $(21,22)$. The fungal genus identification is carried by observing the macroscopic (growth, color, colony) and microscopic examination (mycelium, conidiophore, conidia, resistance structures, sexual form) (23).

\section{Pathogenicity assay}

The experiment was carried out in the greenhouse on date palm cv. Barhi by artificial inoculation. The seedlings were placed in a pot containing a mixture of peat moss and vermiculite (1:1). Both compounds were autoclaved twice at $120^{\circ} \mathrm{C}$.

For Alternaria sp., the assay was carried out by spraying the leaves of each seedling (4 months old) by $5 \mathrm{ml}$ of conidial suspension $\left(10^{5}\right.$ conidia per $\left.\mathrm{ml}\right)$ for each palm trees leaf of Alternaria sp. (4 days old).

The pathogenicity of Fusarium sp. was established according to the standard method (24). Roots of each palm trees seedling ( 4 months old) were inoculated with $10 \mathrm{ml}$ of spore suspension of Fusarium sp. $\left(10^{6}\right.$ spores $\left./ \mathrm{ml}\right)$.

The isolated phytopathogens were inoculated separately and in combination. The plants were covered with a transparent plastic to ensure high humidity of $70-90 \%$ during 3 days after inoculation to ensure the infection occurred.

Only one control was performed; by inoculating the date palm seedlings with sterilized distilled water (negative control). The pots were then placed in a greenhouse for two weeks with nine date palms seedlings per treatment and per replicate. The entire experiment was repeated three times (21).

The evaluation parameters were measured within four week following inoculation. Area of observed symptoms were scored for disease index using a scale from 0 to 4; 0 = no spots; 1 = number of spots covering leaf about 1-3 spots, with yellowing of $1-25 \%$ of the leaf area; $2=$ number of spots covering leaf about 4-6 spots, with yellowing of $26-50 \%$ of the leaf area; 3 = number of spots covering leaf about 7-9 spots, with yellowing of $51-75 \%$ of the leaf area; $4=$ spots covering the totality of leaf, with yellowing of $75-100 \%$ of the leaf area. The severity data were processed by McKinney's formula, which generates a numeric disease severity index (DSI): DSI (\%) = $(\Sigma \mathrm{vn}) /(\mathrm{NV}) \times 100$, where $\mathrm{V}$ represents the numeric value of the disease index scale, $n$ is the number of plants assigned to the disease index scale, $\mathrm{N}$ is the total number of the plants and $\mathrm{V}$ is the numeric value of the highest disease index scale. DSI was calculated from five leaves of each date palm seedlings (21).

\section{In vitro evaluation of fungicides against the isolated phytopathogens}

Only the most virulent phytopathogen (Alternaria sp.) was used for the in vitro and in vivo evaluation of fungicides. 
Relative efficacy of fungicides on mycelial growth inhibition of the isolated phytopathogens was studied in vitro, using poisoned food technique (25). In this experiment, two fungicides (Score $(1 \mathrm{ml} / \mathrm{l})$ and Pentanol (3 ml/l)) were used for their efficacy $(26,27)$. The fungicide suspension was made by adding required quantity of fungicides to the molten potato dextrose agar (PDA) medium to obtain the desired concentration (three concentrations; $100 \%$ of commercial recommended dose, $200 \%$ of commercial recommended dose, and $300 \%$ of commercial recommended dose) on the basis of active ingredient present in the chemical (25). Fourteen milliliter of amended medium was poured into each sterilized petriplates and suitable checks were maintained. One mycelial disc plug $(0.5 \mathrm{~cm}$ diameter) of pathogen (4 days-old culture) was placed in the center of the plate. A plug of pathogen was used as control treatment (without treatment). Three replicates for each individual treatment were conducted and the plates were incubated at $25 \pm 2{ }^{\circ} \mathrm{C}$ receiving fluorescent light with $12 \mathrm{hr}$ cycling for 7 days. The percent of pathogen radial mycelial growth inhibition (I) was evaluated according to this formula: $I(\%)=(1-\mathrm{Cn} / \mathrm{C} 0) \times 100$; where: $\mathrm{Cn}$ is the radial growth diameter of the pathogen in the presence of the treatment. $\mathrm{C} 0$ is the growth diameter of the pathogen in the control treatment (21).

\section{Greenhouse evaluation of fungicides against the isolated phytopathogens}

Date palm seedlings (cv. Barhi) were placed in a pot containing a mixture of peat and vermiculite (1:1); at the rate of one seedling in each pot (180 pots for each treatment and each replicate (Three replicates)). The entire experiment was repeated twice. Treatment application and inoculation were occurred after four months of the date palm growing. This experiment was concerned only with preventive treatments. Each fungicide (only at the recommended dose) was applied separately with 5 date palm seedlings/treatment (4 treatments: T1: Score; T2: Pentanol; T3: Positive control and T4: Negative control). The treatment application was carried out by spraying the date palm leaves 3 days before the inoculation of the conidial suspension of the pathogen. All seedlings were inoculated at the same time with a spore suspension of $10^{6} \mathrm{CFU} \backslash \mathrm{ml}$ of the isolated phytopathogens obtained from 7-day-old cultures grown on PDA medium. Fungicides were applied to date palm using a hand-held sprayer at a volume of $40 \mathrm{ml}$ per seedling. Immediately after inoculation plants were enclosed in plastic bags for $24 \mathrm{hr}$ to optimize conditions suitable for infection. The pots were then placed in a greenhouse for two weeks. Assessments were conducted 15 days after inoculation by measuring disease severity index. DSI was calculated from five leaves of each date palm seedlings $(21,27)$.

\section{Statistical analysis}

The data were analyzed by ANOVA using SPSS version 20.0 statistical software (SPSS, SAS Institute, USA), to evaluate parameter values differences. Differences between treatments were determined by least significant difference (LSD) test at $5 \%$ of significance level.

\section{Results and Discussion}

\section{Phytopathogens isolation from date palm}

We successfully isolated two phytopathogens species (Alternaria sp. and Fusarium sp.) based on their visual morphological characterizations from the diseased leaves of date palm cultivated in Basra, Iraq (Fig. 1). The isolation frequencies of these phytopathogens species were showed that the higher was registered for Alternaria sp. (89\%), followed by Fusarium sp. (9\%), Trichoderma spp. (1.7\%), Aspergillus sp. (0.2\%) and Penicillium sp. (0.1\%). Several research works from different date palm growing areas of the world reported various fungal pathogens (Fusarium sp. and Alternaria sp.) associated with the symptoms we detected $(14,16,28$ 30).

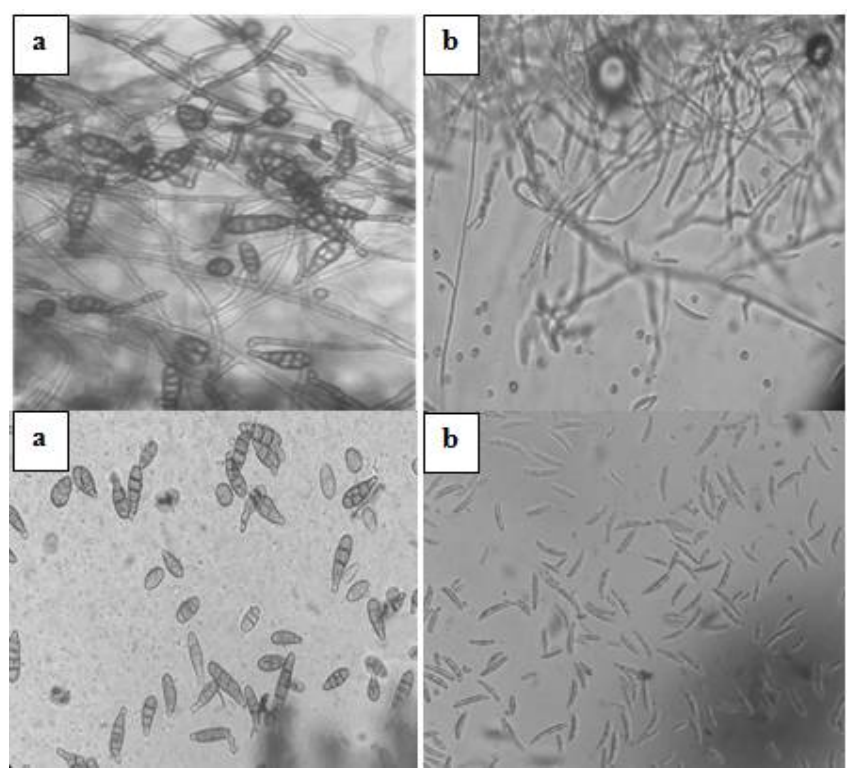

Fig. 1. The isolated phytopathogens on date palm. a) Alternaria sp.; b) Fusarium sp.

\section{Pathogenicity assay}

The results of pathogenicity test of Alternaria sp. and Fusarium sp. exhibited high degree of pathogenicity according to the measured DSI. Statistical analysis revealed a significant difference of DSI $(\mathrm{P}<0.01)$. Variations in pathogenicity level were indicated between the isolated phytopathogens. Alternaria sp. inoculated separately or in combination with Fusarium sp. was highly virulent to date palm leaf with DSI values 67.33 and $65.99 \%$, respectively. It was pathogenic 14 days after inoculation (Table 1). Symptoms initially appeared on the leaves in the form of small yellow spots in the form of concentric circles then turned brown surrounded by halo furs and the progress of the injury takes spots broad (Fig. 2). Present results are in analogy with (31-34) which reported the pathogenicity of Alternaria sp. (DSI = $70 \%$ ) and Fusarium sp. (DSI $=50 \%$ ) on date palm. The isolated species of Fusarium sp., Alternaria sp., Mycosphaerella sp., Diplodia sp., Phomopsis sp., 
Chaetosphaeropsis sp., Botryodiplodia sp., Omphalia sp. and Phoma sp. were recorded as fungal pathogens of date palm trees on the basis of pathogenicity examinations $(15,34)$. The varieties used in the discussion part are moderately resistant to Fusarium sp. and Alternaria sp.

Table 1. Pathogenicity of the isolated phytopathogens

\begin{tabular}{lc} 
Treatments & Disease severity index (\%) \\
\hline Negative control & $0 \pm 0$ \\
\hline Alternaria sp. & $67.33 \pm 0.77$ \\
\hline Fusarium sp. & $55.89 \pm 0.52$ \\
\hline Alternaria sp. + Fusarium sp. & $65.99 \pm 0.96$ \\
\hline LSD $_{0.05}$ & $<0.01$ \\
\hline Da
\end{tabular}

Data are the average of 3 date palm seedlings per treatment and per replicate (with 3 replicates).

Disease severity index was calculated from five leaves of each date palm seedlings.
Statistically, significant increase in mycelial growth inhibition was observed with an increase in concentration of commercial recommended dose. The highest inhibition percent was registered at $300 \%$ of commercial recommended dose and obtained data ranging from 82.91\% (Pentanol) to 88.76\% (Score). However, the lowest inhibition was recorded at $100 \%$ of commercial recommended dose. It can be concluded that Score seemed to be the most effective treatment with inhibition rate above $77.79 \%$ under in vitro conditions (Table 2). These findings are in concordance with those of (13) showed that Score, Cuprosate, Mizeb and Carbendazim provided highly significant mycelial growth inhibition with $90 \%$. In another study, there are reports stating that score is capable of decreasing the mycelial growth and colonization of Alternaria sp. and inhibited their

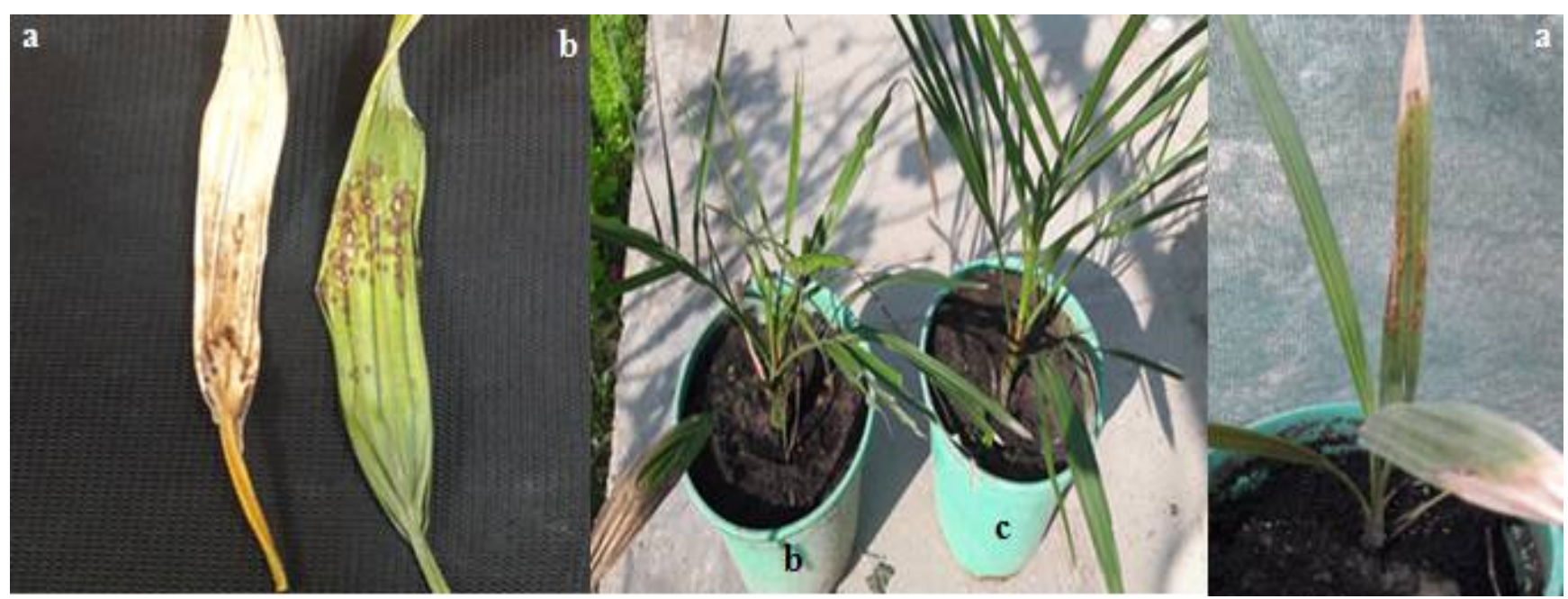

Fig. 2. Symptoms of artificial inoculation of Alternaria sp. applied separately (a) or in combination with Fusarium sp. (b) comparing with the negative control (c) on date palm.

Table 2. Effect of two fungicides on mycelial growth inhibition of Alternaria sp. after 7 days of incubation at $25 \pm 2{ }^{\circ} \mathrm{C}$

\begin{tabular}{|c|c|c|c|}
\hline \multirow[b]{2}{*}{$\begin{array}{l}\text { Treat } \\
\text { ments }\end{array}$} & \multicolumn{3}{|c|}{ Concentrations } \\
\hline & $\begin{array}{l}100 \% \text { of } \\
\text { commercial } \\
\text { recommended } \\
\text { dose }\end{array}$ & $\begin{array}{l}200 \% \text { of } \\
\text { commercial } \\
\text { recommended } \\
\text { dose }\end{array}$ & $\begin{array}{l}300 \% \text { of } \\
\text { commercial } \\
\text { recommende } \\
\text { d dose }\end{array}$ \\
\hline Score & $77.79 \pm 0.37$ & $79.81 \pm 0.28$ & $88.76 \pm 0.75$ \\
\hline $\begin{array}{l}\text { Pentan } \\
\text { ol }\end{array}$ & $68.96 \pm 0.85$ & $71.03 \pm 0.90$ & $82.91 \pm 0.66$ \\
\hline $\mathrm{LSD}_{0.05}$ & \multicolumn{2}{|c|}{$\begin{array}{l}\text { For concentrations }=2.13 \\
\text { Interaction }=1.01\end{array}$} & $\begin{array}{l}\text { For pesticides } \\
=1.74\end{array}$ \\
\hline
\end{tabular}

Data are the average of 3 Petri dishes per treatment per replicate (with 3 replicates).

Alternaria spp. proved to be pathogenic on date palm leaves. This agrees with previous studies that indicated the prevalence of this genus and its pathogenicity on date palm leaves $(16,30)$.

Only the most virulent phytopathogen (Alternaria sp.) was used for the in vitro and in vivo evaluation of fungicides.

\section{In vitro evaluation of fungicides against the isolated phytopathogens}

Data presented in Table 2 demonstrated clearly that the two fungicides exerted high significant reduction on radial mycelial growth of Alternaria sp. after 7 days of incubation using poison food technique. sporulation and spore germination $(25,34)$. The active ingredient of both fungicides has the potential to limit the growth of a wide range of pathogens (21, 22).

\section{Greenhouse evaluation of fungicides against the isolated phytopathogens}

The disease severity index showed that the treatments fungicides differed significantly $(\mathrm{P}<0.01)$ (Table 3$)$. Foliar treatment of date palm seedlings with Pentanol in the presence of Alternaria sp. reduced significantly the DSI with $17.87 \%$, followed by treatment with Score $(22.65 \%)$ (Table 3). It was demonstrated that foliar treatment with difenoconazole decreased the disease incidence and severity (25). Similar results were obtained with Swift (Carbendazim 50\%) reporting that the disease incidence was ranged from $23.4 \%$ to $6.3 \%$ (North of Basra) and from $6.8 \%$ to $1.9 \%$ (South of Basra) after date palm fungicide treatment with Swift. The disease severity was 18\% (North of Basra) and $12.7 \%$ (South of Basra) and reduced significantly up to $4.7 \%$ and $4.3 \%$ (12). There are several reports demonstrated that Score, Pentanol, Benlate, Bayleton, Tilt, Ortiva, Naturame, Phyton-27, Revus Top and Dazim have been used to control different fungal pathogens on date palm under in vivo conditions (13, 23, 36-39). 
Table 3. Disease severity index (DSI) recorded on date palm leaf inoculated with Alternaria sp. $\left(10^{5}\right.$ conidia per $\left.\mathrm{mL}\right)$ and treated separately by two fungicides

\begin{tabular}{lc}
\hline Treatments & Disease severity index (\%) \\
\hline Negative control & $0 \pm 0$ \\
\hline Positive control & $60.83 \pm 1.05$ \\
\hline Score $(1 \mathrm{~mL} / \mathrm{L})$ & $22.65 \pm 0.86$ \\
\hline Pentanol $(3 \mathrm{~mL} / \mathrm{L})$ & $17.87 \pm 0.49$ \\
\hline $\mathrm{LSD}_{0.05}$ & $<0.01$ \\
\hline
\end{tabular}

Data are the average of 5 date palm seedlings per treatment per replicate (with 3 replicates).

Disease severity index (DSI) was calculated from five leaves of each date palm seedlings.

DSI $(\%)=(\Sigma v n) /(N V) \times 100$, where $v$ represents the numeric value of the disease index scale, $\mathrm{n}$ is the number of plants assigned to the disease index scale, $\mathrm{N}$ is the total number of the plants and $\mathrm{V}$ is the numeric value of the highest disease index scale. DSI was calculated from five leaves of each date palm seedlings.

There are reports stating that the Difenoconazole and Pentanol are capable of decreasing of the mycelial growth and colonization of Alternaria solani and inhibited their sporulation and spore germination $(25,39,40)$. The high concentration of fungicides had a good inhibitory effect on the growth of plant pathogen fungi and reduced disease severity. The mycelial growth inhibition and the disease severity reduction were significantly higher with the high concentrations of fungicides (41-43). The appressorium is an important fungal structure during the penetration process; therefore, this fungicides show a spore germination inhibition and appressorium formation blocking $(39,40)$. Studies also revealed that the active ingredient could be responsible for their higher antifungal activity against fungal plant pathogen (39-44).

\section{Conclusion}

Alternaria sp. and Fusarium sp. have caused leaf spot and yellowing diseases with isolation frequencies of $89 \%$ and $9 \%$, respectively. The results of pathogenicity test proved the ability of Alternaria sp. to infect date palm leaves. The chemical fungicide Pentanol at the recommended rate was the most effective in controlling Alternaria sp. under in vivo conditions which decreased the disease severity on date palm. Based on the current results, it is deduced that tested Pentanol could be employed in foliar treatments to may induce date palm systemic resistance, through a specific signal transduction cascade. The systemic resistance induction of date palm by Pentanol against Alternaria sp. is a subject of future research. The fungicides used have wide-ranging effects, and it seems likely that the treatment with fungicides killed both pathogenic fungi as well as beneficial micro organism (mycorrhiza, antagonitic etc). For this reason, we must appeal to integrated pest management strategies on integrating different approaches (chemical control, biological control, prophylactic technique, genetic control etc), while reducing the use of fungicides.

\section{Acknowledgements}

The authors are grateful to the review editor and the anonymous reviewers for their helpful comments and suggestions to improve the clarity of the research paper.

\section{Authors' contributions}

All authors contributed equally to this work.

\section{Conflict of interests}

The authors declare that they have no conflict of interest. This article does not contain any studies with human participants or animals performed by any of the authors. Informed consent was obtained from all individual participants included in the study. All authors have approved the manuscript for submission.

\section{References}

1. Al-Shahib W, Marshall RJ. The fruit of the date palm: it is possible use as the best food for the future. Int J Food Sci Nutr. 2003;54:247-59. http://dx.doi.org/10.1080/09637480120091982

2. Chao CC, Krueger R. The date palm (Phoenix dactylifera L.): overview of biology, uses and cultivation. HortScience. 2007; 42(5):1077-82. https://doi.org/10.21273/HORTSCI.42.5.1077

3. Rhouma A. L'oasis de Chott Sidi Abdel Salam, Gabés, Tunisie: Réalités et défis. Allemagne: Editions universitaires européennes; 2017. p. 144

4. Rhouma A, Mougou I, Rhouma H. Determining the pressures on and risks to the natural and human resources in the Chott Sidi Abdel Salam oasis, southeastern Tunisia. Euro-Mediterr J Environ Integr. 2020;5:37. https://doi.org/10.1007/s41207-020-00176-W

5. El-Juhany LI. Degradation of date palm trees and date production in arab countries: Causes and potential rehabilitation. Aust J Basic Appl Sci. 2010;4(8):3998-4010.

6. Zaid A, De Wet PF, Djerbi M, Oihabi AC. Diseases and pests of date palm in date palm cultivation. Plant production and protection Baghdad, Iraq: FAO; 2002. p. 227-81.

7. Abdelmonem AM, Rasmy MR. Major diseases of date palm and their control. Commun Inst for Bohem. 2007;23:9-23.

8. Rhouma A, Bedjaoui H, Atallaoui K, Matrood AAA, Mehaoua MS. Le palmier dattier, le bayoud et la lutte intégrée: une revue sur la question. Germany: Noor Publishing; 2021.

9. Abdul Sattar MH, Rashid Yassin Ibrahim A, Aulaqi WA Occurrence of false smut on date palm (Phoenix dactylifera L.) in the southern coastal plains of Yemen. J Appl Hortic. 2012;14:144-45. https://doi.org/10.37855/jah.2012.v14i02.27

10. Abass MH, Hameed MA, Ahmed AN. First report of Nigrospora sphaerica (Sacc.) Mason as a potential pathogen on date palm (Phoenix dactylifera L.). Can J Plant Pathol. 2013;35:75-80. https://doi.org/10.1080/07060661.2012.732612

11. Al-Nadabi HH, Maharachchikumbura SSN, Agrama H, Al-Azri M, Nasehi A, Al-Sadi AM. Molecular characterization and pathogenicity of Alternaria species on wheat and date palms in Oman. Eur J Plant Pathol. 2018;152:577-88. https://doi.org/10.1007/s10658-018-1550-4

12. Mansoori B, Kord MH. Yellow death: A disease of date palm in Iran caused by Fusarium solani. J Phytopathology. 2006;154:125-27.

13. ALasadi RMS, Al-Najim EA, Al-Dosary NH. Study of date palm fruit rot caused by Alternaria alternata and it's chemical control. Basrah J Date palm Res. 2006;5(1-2):16-21. 
14. Bokhary HA. Seed-borne fungi of date-palm, Phoenix dactylifera L. from Saudi Arabia. Saudi J Biol Sci. 2010;17(4):327-29. https://doi.org/10.1016/j.sjbs.2010.06.005

15. Ben Chobba I, Elleuch A, Ayadi I, Khannous L, Namsi A, Cerqueira F, Drira N, Gharsallah N, Vallaeys T. 2013. Fungal diversity in adult date palm (Phoenix dactylifera L.) revealed by culture-dependent and culture-independent approaches. J Zhejiang Univ-Sci $\quad$ B. 2013;14(12):1084-99. https://doi.org/10.1631/jzus.B1200300

16. Maitlo WA, Markhand GS, Abul-Soad AA, Lodhi AM, Jatoi MA. Fungi associated with sudden decline disease of date palm (Phoenix dactylifera L.) and its incidence at Khairpur, Pakistan. Pak J Phytopathol. 2014;26(1):65-71.

17. Khudhair MW, Jabbar RA, Dheyab NS, Hamad BS, Aboud HM, Khalaf HS, Mohammed NJ. Alternaria radicina causing leaf spot disease of date palm (Phoenix dactylifera L.) in Wasit (Middle of Iraq) and its susceptibility to bioassay test of two fungicides. Int J Phytopathol. 2015;4(2):81-86.

18. Thomma BPHJ. Alternaria spp.: from general saprophyte to specific parasite. Mol Plant Pathol. 2003;4(4):225-36.

19. El-Morsi MEA, Kamhawy MAM, Sallam MAA. Effectiveness of some organic compounds in controlling pathogenic fungi associated with roots of date palm offshoots in New Valley Governorate, Egypt. Assiut J Agric Sci. 2009;28(40):137-50.

20. Song GC, Chio HK, Ryu CM. The folate precursor paraaminobenzoic acid elicits induced resistance against Cucumber mosaic virus and Xanthomonas axonopodis. Ann Bot. 2013;111:925-34. https://doi.org/10.1093/aob/mct049

21. Rhouma A, Ben Salem I, M’Hamdi M, Boughalleb-M’Hamdi N. Antagonistic potential of certain soil borne fungal bioagents against Monosporascus root rot and vine decline of watermelon and promotion of its growth. Nov Res Microbiol J. 2018;2:85-100. https://doi.org/10.21608/NRMJ.2018.17864

22. Rhouma A, Ben Salem I, Mhamdi M, Boughalleb-Mhamdi N. Relationship study among soils physico-chemical properties and Monosporascus cannonballus ascospores densities for cucurbit fields in Tunisia. Eur J Plant Pathol. 2019;153:65-78. https://doi.org/10.1007/s10658-018-1541-5

23. Fayadh MA, Saleh YA, Lefta DS. Isolation and identification of fungi associated with date palm leaflet blight disease and its chemical and biological control. Basrah J Agric Sci. 2016;29(2):252-65.

24. Boughalleb-M’Hamdi N, Rhouma A, Ben Salem I, M’Hamdi M. Screening and pathogenicity of soil-borne fungal communities in relationship with organically amended soils cultivated by watermelon in Tunisia. JPPM. 2017;4(1):1-16. http://ppmj.net/index.php/ppmj/article/view/82

25. Töfoli JG, Domingues RJ, Kurozawa C. Ação in vitro de fungicidas no crescimento micelial e gernimação de conidios de Alternaria solani, agente causal da pinta preta do tomateiro. Arq Inst Biol. 2003;70(3):337-45.

26. Shaban AN, Al-Malah M. Pesticides. University of Musol-Iraq: Dar Alkutub for printing and publishing; 1993. p. 520.

27. Rhouma A, Ben Salem I, Boughalleb-M'Hamdi N, Gomez JIRG. Efficacy of two fungicides for the management of Phytophthora infestans on potato through different applications methods adopted in controlled conditions. Int J Appl Pure Sci Agric. 2016;2(12):39-45.

28. Abdalla MY, Al-Rokiba A, Moretti A, Mule G. Pathogenicity of toxigenic Fusarium proliferatum from date palm in Saudia Arabia. Plant Dis. 2000;84:321-24.

29. Al-Yasiri NA, Saad AR, Nasser SA, Zaid KM. The relationship between the fungus Fusarium solani and some pathological phenomena on date palm trees and the effectiveness of some systemic fungicide for their control. Paper presented at
Proceeding of the Fourth International Date Palm Conference; Abu Dhabi; United Arab Emirates; 2010 Mar 15-17.

30. Masood A, Saeed S, Silveira SF, Akem CN, Hussain N, Farooq M Quick decline of mango in Pakistan: Survey and pathogenicity of fungi isolated from mango tree and bark beetle. Pak J Bot. 2011;43(3):1793-98

31. Sarhan ART. 2001. A study on the fungi causing decline of date palm trees in middle of Iraq. Proceedings of the 2nd International Conference on Date Palm; 2001 March 25-27; UAE: Al Ain; 2001. p. 424-30.

32. Al-Sharidy A, Molan Y. Survey of fungi associated with black scorch and leaf spots of date palm in Riyadh Area. Saudi J Biol Sci. 2008;15:113-18

33. Farrag ESH, Abo-Elyousr KA. Occurrence of Some Fungal Diseases on Date Palm Trees in Upper Egypt and its Control. Plant Pathol J. 2011;10:154-60. https://doi.org/10.3923/ppj.2011.154.160

34. He MH, Wang YP, Wu EJ, Shen LL, Yang LN, Wang T, Shang LP, Zhu W, Zhan J. Constraining evolution of Alternaria alternata resistance to a demethylation inhibitor (DMI) fungicide difenoconazole. Front Microbiol. 2019;10:1609. https://doi.org/10.3389/fmicb.2019.01609

35. Abass MH, Maziel MM. Chemical control of leaf blight and inflorescence rot diseases on date palm in large- scale field trials in Basrah/ Iraq. Basrah J Date palm Res. 2019;18(1):1-5.

36. Livingston S, Al Mufargi K, Al Suhkeli M. Chemical control of leaf spot of date palm (Phoenix dactylifera) in sultanate of Oman. Plant Pathol https://doi.org/10.5423/PPJ.2002.18.3.165

37. Maitlo WA, Markhand GS, Abul-Soad A, Lodhi AM, Jatoi MA. Chemical control of sudden decline disease of date palm (Phoenix dactylifera L.) in Sindh, Pakistan Pak J Bot. 2013;45:711.

38. Saeed EE, Sham A, El-Tarabily K, Abu Elsamen F, Iratni R, Abu Qamar SF. Chemical control of black scorch disease on date Palm caused by the fungal pathogen Thielaviopsis punctulata in United Arab Emirates. Plant Dis. 2016;100(12):2370-76. https://doi.org/10.1094/PDIS-05-16-0645-RE

39. Horsfield A, Wicks T, Davies K, Wilson D, Paton S. Effect of fungicide use strategies on the control of early blight (Alternaria solani) and potato yield. Australasian Plant Pathol 2010;39:368-75. https://doi.org/10.1071/AP09090

40. Stepanović M, Jevremović S, Rekanović E, Mihajlović M, Milijašević-Marčić S, Potočnik I, Todorović B. In vitro sensitivity of Alternaria solani to conventional fungicides and a biofungicide based on tea tree essential oil. Pestic Phytomed. 2015;30(1):25-33.

41. Bekker TF, Kaiser C, Merwe R, Labuschagne N. In-vitro inhibition of mycelial growth of several phytopathogenic fungi by soluble potassium silicate. S Afr J Plant Soil. 2006;23(3):169 72. https://doi.org/10.1080/02571862.2006.10634750

42. Kopacki M, Wagner A. Effect of some fungicides on mycelium growth of Fusarium avenaceum (Fr.) Sacc. pathogenic to chrysanthemum (Dendranthema grandiflora Tzvelev). Agron Res. 2006;4:237-40.

43. Shin JH, Fu T, Park KH, Kim KS. The effect of fungicides on mycelial growth and conidial germination of the ginseng root rot fungus, Cylindrocarpon destructans. Mycobiology. 2017;45(3):220-25. https://doi.org/10.5941/MYCO.2017.45.3.220

44. Dalili A, Bakhtiari S, Barari H, Aldaghi M. Effect of some fungicides against the growth inhibition of Sclerotinia sclerotiorum mycelial compatibility groups. J Plant Prot Res. 2015;55(4):35461. https://doi.org/10.1515/jppr-2015-0047 